The directorate's first task is basic survey and mapping, and since it was established in 1946 it has mapped over 1,654,000 square miles of territory; over 220,000 square miles of this have already been remapped. This surveying and mapping is a continuing process; first, accurate maps are needed for planning development schemes; then as the plans become reality new and more detailed maps are required during the different stages of development. The change from tribal to individual land tenure, together with the rapid urban development in overseas countries, has also led to more demands for large scale mapping, and an increasing proportion of the directorate's mapping activity has been spent on this type of work.

During the year, assistance was given to forty-six countries. In 1966-67, 532 new maps were published, compared with 514 in 1965-66: 180 of the new maps are at a scale of $1: 5,000$ or larger. In addition, reproduction material of 96 new maps was supplied to overseas governments for local publication. The maps are plotted at the headquarters at Tolworth from air photography and the surveyors' work. The plots are then sent to the country concerned for completion in the field by the survey department of detail not visible on the photographs and for the addition of names. The final maps are then scribed or fair-drawn and most are sent to the Ordnance Survey for printing.

An important feature of the year, says the report, has been the continued expansion of the Land Resources Division to enable the directorate to meet the requests for scientific investigations to aid development planning overseas. The division worked for sixteen countries and carried out field investigations in six. Training attachments for officers from overseas technical departments form an important part of the directorate's aid to developing countries. Senior members of the staff are also seconded to overseas governments. At headquarters, research into new techniques, equipment and materials for mapping continued to be carried out, and exhaustive field tests were made on the MRA 3 and MRA 101 tellurometers in southern Nigeria.

\section{Safety in School}

A NEWLY revised version of the pamphlet Safety at School has just been published by the Department of Education and Science (HMSO, 9s.). It replaces a similar pamphlet first published in 1948 and refers in particular to fire precautions and electrical safety. The pamphlet says that there are positive and negative sides to safety; the aim of safety precautions should not be to eliminate every possibility of accident but to avoid unnecessary risks so that children can face up confidently and sensibly to those which cannot, or should not, be avoided.

Improvements in design have helped to make schools safer and more efficient. Serious accidents are, fortunately, comparatively rare. Figures for the total number of serious accidents do not appear to be available, though no doubt individual local authorities retain records. The chapter on road safety is the most disturbing. Road accidents are responsible for half the total of accidental deaths in childhood. Between 1961 and 1965, fatal and serious casualties in the 5-19 age group increased by 29 per cent, compared with a rise of 15 per cent for the population as a whole.
Schoolchildren seem to be taking to the air in sufficient numbers for the pamphlet to include a new chapter on that subject. There is also a new appendix on precautions in the use of electricity, and the chapters dealing with safety in science laboratories and workshops and with safety afloat have been re-written and brought up to date. The chapters on safety in science laboratories and workshops could be profitably read by practising scientists and technologists outside schools.

\section{How Eskimos Adapt}

How have Eskimos become adapted to extremes of climate? This is a question which an international study undertaken by the United States, Canada, France and Denmark may help to answer. The idea for the study arose at a recent conference on circumpolar peoples held at Point Barrow, Alaska, under the sponsorship of the International Biological Programme (IBP). Eskimos are particularly interesting because over the centuries they have migrated considerable distances and have been exposed to extremely hostile conditions. The purpose of the study, which will be conducted under the auspices of the IBP, is to measure the way in which genetically similar groups of Eskimos have adapted to the varying environments along the routes of migration: to do this, research sites have been situated at points along these routes.

Danish and French investigators will investigate Eskimo adaptation at Upernavik in north-eastern Greenland-one of the most distant points in the Eskimo migratory pattern; the US research will be directed in the vicinity of Wainwright, Alaska, while the Canadians will work at Iglook in the North-west Territories--the centre of the circumscribed migration route.

The US study was developed by the Human Adaptability Sub-committee of the US National Committee for the IBP and is under the direction of Dr Frederick A. Milan of the University of Wisconsin. According to Dr Milan, it is hoped that their study at Wainwright will determine the way in which "an Eskimo community on the Arctic coast of Alaska has successfully perpetuated itself under severe climatic conditions with relatively meagre resources". In addition, by studying the patterns and habits of Eskimo life, an insight might be provided into human adaptability and evolution in general. Scientists from the Universities of Wisconsin, Chicago, Indiana, Oregon, California at Los Angeles, the State University of New York at Buffalo and the Wisconsin State Laboratory of Hygiene will all participate in the US effort. Among the aspects of research will be behaviour, psychology and mental illness, ecology, environmental studies, genetic markers, growth and development, local climate and geography, and population history. By co-ordinating the data from each of the four countries, an overall picture of Eskimo migration can be built up.

According to the IBP headquarters in London, similar studies are being carried out by the Russians and Scandinavians as part of the large-scale investigation of circumpolar peoples. The Finns have already completed some work near the Russian border on the distribution and habits of Lapps and are hoping to extend this work. 